\title{
American literature(s) in Motion: Migration, IMAGINATION, AND IDENTITY IN CONTEMPORARY U.S. FICTION
}

\author{
Selma Raljević, Džemal Bijedić University of Mostar, Bosnia and \\ Herzegovina, selma.raljevic@gmail.com
}

Original scientific paper

DOI: 10.31902/fll.33.2020.1

UDC: $821.111(73) .09$

\begin{abstract}
This article analyzes the remaking of American literature and its identity, focusing transnational American literature in general and, in particular, the contemporary American novel. It discusses a sense of postnational and anational motion of/in U.S. fiction, with an emphasis on the $21^{\text {st }}$ century American novel, created by both American and non-American authors and observed from a perspective of both American and non-American Americanists. Aimed at exploring literature in motion across "imagined" borders, the article also discusses the synergies between literature and other arts and disciplines in contemporary American literatures in order to provide new insights into literature in general and American literatures in particular. In the dialogue of literature with other disciplines, it examines the synergies between the local, regional, national, and global in contemporary U.S. fiction, as well as the synergies between different discourses of contemporaneity. Moving beyond established models in the way that even the term "transnational" transcends its own definition, the aim is to newly theorize a transnational/post-national/anational as well as transtextual motion of/in American fiction toward new directions of both American and non-American creation of American literatures.
\end{abstract}

Keywords: Migration, Imagination, Identity, Motion, Contemporary Transnational American Literatures.

Even though it is arguable where a genealogy of the U.S. begins, as well as it is not quite clear, to use Yogita Goyal's words, "where a genealogy of transnationalism should begin" (2), the genealogy of the U.S., including its beginning(s), could be seen in a transnational optic as an acknowledgement of interconnectedness of the U.S. with the rest of the world through circuits of migrations of people, objects, and ideas from the "discovery" of America through a lens of "deep time" (Dimock, Through Other Continents: American Literature Across Deep Time) to the present time. America - the national, post-national, 
transnational, anational America, and all of these "Americas" in motion and/or intertwined - has also been "discovered" in literature. For imagination goes beyond the boundaries of knowledge and embraces the whole world, to paraphrase Albert Einstein's widely quoted words, literature enables imagination to transcend its subject and requires finding new ways of seeing and understanding. Literature, as well as art in general, represents what the philosopher Jonathan Lear calls radical hope. "What makes this hope radical," Lear argues, "is that it is directed toward a future goodness that transcends the current ability to understand what it is" (103). Although the U.S. has always been divided, and the issues of race and ethnicity continued to be unresolved even in the time of Barack Obama's presidency and allegedly post-racial America, as well as in the so-called post-American century that has widely been characterized by the American rejection of the ideology of "American exceptionalism," the U.S. in the Donald Trump era has gone enormous steps backwards and become sharply divided between American "Ur-Fascism," to use Umberto Eco's term signifying "Eternal Fascism," and anti-fascism. The "post" of postAmerican century implies a critical category that serves to decenter the ideology of American empire and its concept of ideological Americanness rather than a temporal signifier. Hence, the division of the $21^{\text {st }}$ century America into the "two Americas" has intensified. As the U.S. "cannot be separated from its fiction" (Nafisi 6), even though its fiction, as well as literature in general, in Azar Nafisi's words, is the Republic of Imagination that is "a land with no borders and few restrictions" (4), literature of the U.S. is, in many ways, an intellectual resistance to an unintellectual reality and, at the same time, it is an alternative ontology (as opposed to "alternative facts"). Among other things, contemporary American literatures in general and, in particular, transnational American literatures engage, rather than merely project, an expression of a post-national evolution of trans-American experience and imagination that is transnational and/or anational in the way of radical hope as it refers to the changes of un-thinking and re-thinking the concepts of "nation" and "nation-state" tied to a perception and feelings of identity and, paradoxically at the same time, it is American at its best for it points the way toward a libertarian future of a nation of different nations, ethnicities, and cultures. Simultaneously, some forms of contemporary American literatures, including some movements of the transnational frame, demonstrate how much literature moves with literature's migration toward some new platforms and formats of trans-discursive, trans-artistic, and/or transmedia storytelling, and thus transcending borders and boundaries 
of the canonical literary expression. Taken all together, literary motion and mobility could be understood as a catalyst for modes of thinking that create change against stagnation and retrogression, as well as the vision of what might be, while retaining a core sense of the past and present, so as to provide a sense for the visionary or creative perceptions of future possibilities that often transcend the current ability to understand what they are. This calls for, among other things, a new literary ontology of the present ${ }^{1}$. The mobility of literature leads to a new literary reality and a new way of conceptualizing a contemporary literary "being." This essay is a step toward the way of seeing and articulating the "more" of a fraction of the vision of American and trans-American literatures, and its goal is thus to provide a new interpretation of U.S. literature of/in transcendental motion or "trans/motion."

1. A Poetics of Contemporary Transnational/Postnational/Anational "U.S. Fiction of/in Trans/motion"

Transnationalism itself could be seen as an alternative ontology. It could be defined in many ways as it could mean different things to many people. In any way, it provides an alternative perspective of individual as well as of collective identity. At its worst, as Yogita Goyal points out in her introduction to The Cambridge Companion to Transnational American Literature, a transnational frame "may reiterate exceptionalist legacies that link Americanization to progress and modernity and suggest the inevitability of U.S. domination of the world, keeping the canonical text at the center with a few ethnic exceptions that prove the rule" (6). However, at its best, in Goyal's words,

a transnational approach can unsettle nationalist myths of cultural purity, reveal through comparison the interconnectedness of various parts of the world and peoples, and offer an analysis of past and present imperialisms. It can help map the increasing awareness of cross-cultural dialogue of the Information Age, where the diffusion of cultural forms through immigration and the spread of capital and

\footnotetext{
${ }^{1}$ In his essay "The Ontology of Motion," Thomas Nail says: "The present, however, is not homogeneous, closed set of things and dates. The present is not a presence but an open process, a site of material and performative struggle. Yet this idea itself of the present as an 'open site of struggle' is also a recent historical invention that assumes the mobility of the present to become different than it is" (48).
} 
commodities is ubiquitous and dazzling in both speed and reach. No longer viewing literature as the expression of a national essence, transnational approaches radically reformulate the basic object and scope of literary analysis in and about the United States. Moving beyond the usual impasse of America as empire or colony, exception or exemplar, the transnational turn offers a valuable occasion for examination and critique. Because the transnational frames do not argue for the demise of nations, but for a rethinking of them, they can help counteract triumphalist discourses of globalization. Rather than simply resorting to a premature celebration of a post-national or globalized world, transnationalism becomes the occasion for the questioning of nation and alternative formations to the nation - like world systems and world literature - by emphasizing the flows and migration but also revealing the synergy of cultural and economic aspects of such histories. (6-7)

In Steven Vertovec's definition, transnationalism "broadly refers to multiple ties and interactions linking people or institutions across the borders of nation-states" (1).

Even though transnational literature(s) has always been an inseparable and inextricable part of American literature(s), transnationalism became one of its dominant features in the early 1990s. The current challenges faced by scholars all over the world are to understand, analyze, and rethink motions, changes, and counterchanges of what is defined as transnationalism in literature, culture, thought and life in general, originally arising from wide-scale and farreaching changes in the world in the late $20^{\text {th }}$ and early $21^{\text {st }}$ centuries. For example, the new understanding of American cultural pluralism and America's essential interconnectedness with the rest of the world has been referred to as "the transnational turn." Even though the concept existed before, the phrase is coined by Robert Gross in his 2000 article "The Transnational Turn: Rediscovering American Studies in a Wider World" in Journal of American Studies. This thesis is then expanded by Shelley Fisher Fishkin in her 2004 Presidential Address to the American Studies Association in Atlanta, GA. By pointing out that America should be viewed as a place "always in process itself," as David Palumbo-Liu puts it, Fishkin asserts that the proper role of American studies is to examine "the inside and outside, domestic and foreign, national and international, as interpenetrating" (26). Contemporary scholars such as Amy J. Elias, Christian Moraru, John D. Pizer, Alan Kirby, Wai Chee Dimock, Paul Giles, and many others (Elias and Moraru, The Planetary Turn: Relationality and Geoaesthetics in the 
Twenty-First Century) have recently argued that transnationalism is also interconnected with the new theories of "planetarity" and "planetary turn" obtaining in the essential ethical relations across the "imagined" borders in the social world(s). The contemporary anational motion of/in American literature(s), society, and culture opens up America in itself and to the world, as well as the world to America, all being experienced, expressed, and recognized in new ways of relationality and creative unlimitations. Wai Chee Dimock, for example, "un-thinks" and "re-thinks" American literature(s) across denationalized space of "deep time." In her definition, deep time "gives us a set of coordinates at once extended and embedded, as finegrained as it is long-lasting, operating both above and below the plane of the nation. The subnational and the transnational come together here in a loop" (Through Other Continents: American Literature Across Deep Time 23). Dimock's "un-American" reconceptualization and redefinition of American literature(s) in its "conforming neither to a national chronology nor to a national map" binds together space and time, continents and ages (123). Given the large-scale history of the U.S. in its interconnectedness with the rest of the world, Dimock emphasizes that

the prenational emerges, along with the post-national, as two domains of evidence that cannot be simply written off the temporal map, falling as they do on either side of the nation, bearing a diacritical relation to it. The transnational axis dissolves the field's autonomized chronology, meshing it with a continuum still evolving, and stretching as indefinitely into the past as it does into the future. There are many levels of aggregation here - many "sets" - to which U.S. history might be reintegrated as a subset. These aggregates, by their very nature, require alternate geographies - a span of five continents, no less - a world atlas of which the national map is inextricably a part. These are the longitudes and latitudes needed in order to examine U.S. history as a "nested" phenomenon, cradled by the history of the world. ("Introduction: Planet and America, Set and Subset" 7-8)

Furthermore, Caren Irr in her 2014 book entitled Toward the Geopolitical Novel: U.S. Fiction in the Twenty-First Century argues that a U.S. author is one who addresses a U.S. audience. My understanding of "U.S. fiction" coincides with Irr's in that

a work counts as part of "U.S. fiction" not on the basis of the author's birthplace, citizenship, current residence, or workplace. Any of these biographical factors may be pertinent to any individual author's 
narrative, but no single data point (or combination) defines Americanness ... More important than biographical markers ... is an explicit effort to address a North American audience. The inclusion of major or minor American characters who are in some way educated by the international scene but are otherwise incidental to the story is one major indication that an author is addressing an American audience. Other signals of this concern include the preoccupation with correcting stereotypical American ideas about a particular region or the (often inverted or displaced) use of a common American narrative, such as the upwardly mobile immigrant story. In general, I view internal evidence such as voice, style, and narrative frame as more reliable indicator of a particular work's having an American reference point than authorial biography. (11)

The motion of/in American literature(s) toward post-national, anational, and visionary sense of both American and non-American creation of American literature(s) in the late $20^{\text {th }}$ and $21^{\text {st }}$ centuries seems to be a moment in the history of the institution of literature, as well as in the history of the world in general and, in particular, of the U.S., when transnational American literature(s) and its impulse to transcend itself from a descriptive concept toward a creative sense of denationalized human motion in the world as seen as a commons turn out to be a matter of necessity in both creative literary practice and critical analysis. According to Thomas Nail, "[t]he twenty-first century will be the century of a migrant" (The Figure of the Migrant 1). Analogously, the twenty-first century literature is already, among other things, characterized by an ontology of migration, aesthetics of relocation and/or dislocation, and nation-transcending phenomena, as well as by the synergies between the local, regional, national, and global in contemporary world, including the synergies between the ethnic, racial, and religious. In contrast to Trump and an anti-American Americanness á la Trump, transnational/post-national/anational American literatures appear to reflect as well as shape many key features of contemporary human experience, configuring the realm of transgressed borders and articulating a voice of unassimilable identity of alterity. In Yogita Goyal's understanding, "transnationalism serves as a replacement for the outdated category of multicultural literature, and as an acknowledgement of the interconnectedness of the United States with the rest of the world through circuits of capital and culture" (7).

Transnational/post-national/anational literary expression embraces the uncountable movements, motilities, mobilities, 
migrations, transmigrations, metamorphoses, changes, and actions in contemporary "U.S. literature of transcendental motion or trans/motion," which is the umbrella term I would like to propose instead a narrower rubric and focus of descriptive concepts. The concept of "U.S. literature of trans/motion" is inspired by Gerald Vizenor's theory of "transmotion" especially to "un-think" the idea and "re-think" the vision of transnational American literature and, in particular, of transnational American fiction toward a denationalized evolution of trans-American experience and imagination. In the spirit of this larger inquiry, I propose here a concept of U.S. literature in trans/motion that puts an end to the U.S. imperial discourse and, paradoxically, creates an alternate space where national and transnational/post-national/anational intersect, or even come together in a loop. This concept thus implies the motion of literature. In quite a different aspect, Vizenor's transmotional aesthetics also deals with stories in motion. In his essay "The Unmissable: Transmotion in Native Stories and Literature," Vizenor says: "The discussion of transmotion, a spirited and visionary sense of natural motion, has evolved in my critical studies as an original aesthetic theory to interpret and compare the modes, distinctions, situations, and the traces of motion in sacred objects, stories, art, and literature" (65). In Vizenor's theory, transmotion "is the visionary or creative perceptions of the seasons and the visual scenes of motion in art and literature" (69). Vizenor's theoretical ideas of transmotion in literature could be expanded to observe "a sense of motion that is visionary, more than a mere description, and more than an ethnographic model" ("Re: Your Theory of Transmotion") of the concept of transnational in its motion toward a denationalized, non-descriptive, and natural transcendence in/of (contemporary) U.S. literature as opposed to cultural or social artefacts such as "nationality, or, as one might prefer to put it in view of that word's multiple significations, nation-ness, as well as nationalism" (Anderson 4). One of the framework ideas of an aesthetic of "U.S. literature of trans/motion" is inspired by the following Vizenor's thought:

Consider, for instance, the concept of transmotion and the literary perception of other words with the trans prefix such as transcendentalism, the spiritual sense of natural motion and cultural survivance, or notions of transpacific, transhistorical, transracial, transsexual, and the common practice of transactions. The trans prefix initiates a sense of action or change, a literary and unitary motion, and a wider concept of the motion in images and words. ("The Unmissable: Transmotion in Native Stories and Literature" 64) 
Moreover, Jessica Berman in her 2017 essay entitled "Is the Trans in Transnational the Trans in Transgender?" says that universal answer to such an open comparative question without a singular "allows us to see the important ways that the prefix 'trans' can work to destabilize discourses of both nationality and gender without erasing their specific nuances or foreclosing their possibilities of divergence." She furthermore argues that the prefix "trans" can operate in different levels, and points out that

[t]he transnational shares the oppositional valence of the prefix in such words as "transgress" and "transform" ... When we use the prefix "trans" to mean no just "across, through over ... or on the other side of" but also "beyond, surpassing, transcending," it represents a challenge to the normative dimension of the original entity or space, a crossing over that looks back critically from its space beyond ... The "trans" dimension of the practice of transnational literary study, or of postcolonial or world literature, then, can serve to denaturalize the connection ... between the nation-state and its literary tradition. It also brings attention to the ethical dimension of texts that operate both within and across national horizons of expectations and highlights the political implications of this non-normative movement on both local and global levels ... Thus deployed, the "trans" might become not only a critical optic, practice, or way of reading the texts, bodies, and individuals that operate outside and beyond the (gendered) regime of justice and state citizenship, but also a crucial tool for addressing the complexity of "who" counts as a civic subject or citizen worldwide, and for developing new habits of reading global justice.

Moving beyond established models in the way that even the term "transnational" transcends its own definition, contemporary transnational American literature(s) of a post-American century, with an emphasis on the late $20^{\text {th }}$ and $21^{\text {st }}$ - century American fiction, created by both American and non-American authors, could be seen as a motion of contemporary "U.S. literature of trans/motion." Such an understanding is thus oriented by the trajectory between American and non-American creative sense of contemporary American geoliterary (trans)motion, and then by shaping of, to use Christian Moraru's words, "American Literature Unlimited" (3-4).

A poetics of contemporary transnational/post-national/anational "U.S. fiction of trans/motion," as I conceive it, is being created and shaped by 
1. the writers who are not born in the U.S. but who eventually became the U.S. citizens, so their civic identity is, therefore, dual or multiple;

2. the writers who are "natural born citizens" of the U.S. but who are the descendants of immigrants, or, more generally, the U.S.-born writers whose visionary or creative perception is, in any way, driven by a trans-American sense of identity, affiliation, and equality;

3. the Native American writers who are of mixed Native American and non-Native-American origin, and/or whose visionary and creative perception is in relation to trans-national aesthetics, poetics, and realities in that that their narratives articulate, juxtapose, and/or theorize the various and multidirectional practices as well as sense of the trans-internal (among the Native American nations ${ }^{2}$ themselves) and the trans-external (between the Native American nations, or a certain Native American nation, and the non-Native American nation/nations) motion by migration, trade, and encounter while also keeping their Native American identity, affiliation, and culture strong;

4. the non-U.S. writers (in the matter of citizenship) who address a U.S. audience and write comparatively or solely about the U.S.

Well-known contemporary writers in the first group include Aleksandar Hemon (born in Sarajevo, the former Yugoslavia, in the city which is now the capital of Bosnia and Herzegovina, in 1964, of Ukrainian descent on his father's side and Bosnian, of Serb background, on his mother's side), Azar Nafisi (born in Tehran, Iran, in 1955), Chang-rae Lee (born in Seoul, South Korea, in 1965), Dinaw Mengestu (born in Addis Ababa, Ethiopia, in 1978), Edwige Danticat (born in Port-au-Prince, Haiti, in 1969), Jhumpa Lahiri (born in London, England, in 1967, to Bengali Indian parents), Junot Díaz (born in Santo Domingo, Dominican Republic, in 1968), Laila Lalami (born in Rabat, Morocco, in 1968), Téa Obreht (born as Tea Bajraktarević in Belgrade, the capital of the former Yugoslavia, now the capital of Serbia, in 1985), Viet Thanh Nguyen (born in Ban Me Thouot, now spelled Buon Me Thout, in what was previously known as South Vietnam, in 1971), Rabih Alameddine (born in Amman, Jordan, in 1959, to Lebanese parents), Semezdin Mehmedinović (born in Kiseljak near Tuzla, the former Yugoslavia, now Bosnia and Herzegovina, in 1960; had lived in the United States from 1996, after surviving four years of the war in

\footnotetext{
2 "There are more than 567 federally recognized tribal societies throughout the United States including Alaska, and each in and of themselves is a distinct nation with its own customs, laws, languages, and values that differentiate it from other Indigenous communities as well as the larger colonizing US nation-state" (Byrd 179).
} 
Bosnia and Herzegovina, to 2019, when he returned to live in Bosnia and Herzegovina and, simultaneously, in his mother tongue in which he became a poet and a writer, which he has never abandoned in his literary works). Whether the writers belonging to this group write about the U.S. comparatively or solely, or about some other country/countries, their narratives as well as their own identities and, also, their public engagement demonstrate the myriad of ways in which and how much nationality, nationness, and even nations move. For example, Aleksandar Hemon's novels The Lazarus Project (2008) and The Making of Zombie Wars (2015) are both created in their own way in the transnational, transmigrant, and transcendental dimensions of Slavic-American identity, focusing especially on the countries of Hemon's own "displaced" or "dislocated" identity - Bosnia and Herzegovina, which was formerly part of Socialist Federal Republic Yugoslavia (1945-1991) but gained independence in 1992, and the U.S. - to express many pivotal characteristics of contemporary human existence configuring the realm of transgressed borders with human geography (as opposed to the field of basic geography). The same goes for Semezdin Mehmedinović (but in his own uniqueness), another transnational Bosnian and Herzegovinian writer with American immigrant experience who is also one of Bosnian and Herzegovinian and Post-Yugoslav greatest writers (just like Hemon in his own uniqueness ${ }^{3}$ ), and to some of his books such as, for example, My Heart ${ }^{4}$ (2021). Even though the interconnectedness of the U.S. with the geopolitical coordinates of an unnamed Balkan country as seen as the former Yugoslav in Téa Obreht's debut novel The Tiger Wife (2009), which won the 2011 Orange Prize for Fiction, is not obvious in the novel's narrative without focusing on Obreht's own Slavic-American identity - except for the linguistic origin of the novel in English and its first publication in the U.K. and the U.S. - the novel sets in motion a wider sense of action or change through circuit of images and words, articulating a "linguistic continuum" (Dimock, "Literature for the Planet" 177) which transcends borders and boundaries of nation-states in general and, in particular, between Slavic and American, Slavic and Western, and Slavic-speaking and English-speaking spatialities. Hemon and Obreht are both writers of Slavic descent who have settled in the U.S. and now write in English. In 1992, Hemon, then a Bosnian

\footnotetext{
${ }^{3}$ Hemon is also one of the greatest (transnational) American writers, one of the most acclaimed contemporary writers of literature in English.

${ }^{4}$ Translated by Celia Hawkesworth. Originally published as Me'med, crvena bandana $i$ pahuljica in Croatia, in 2017.
} 
journalist reporting on cultural affairs, came to Chicago on what was supposed to be a month long cultural exchange program, but he was stranded there when his hometown Sarajevo, then a city in Yugoslavia and now the capital of Bosnia and Herzegovina, came under siege at the end of his program, so he was granted political asylum in the U.S. He still lives in the U.S. with his second wife, Teri Boyd (a photographer and photographic editor, artist, and journalist from Florida), and their daughters. In the early 1990s, when a war broke out in what was then Yugoslavia, Obreht (unlike Hemon) was a child. Her family of mixed ethnicity (as well as Hemon's) was not uncommon in the former Yugoslavia before the Balkans war(s) but became the most endangered family composition once the war(s) broke out. At that time, Obreht lived in Belgrade, then the capital of Yugoslavia and now the capital of Serbia. At the beginning of the Balkans war(s), Obreht and her family moved to Cyprus, then Egypt, before she settled in the U.S. together with her mother. She was 12. Viet Thanh Nguyen, a university professor and author, was 4 when he came to the U.S. together with his family after fleeing war-torn Vietnam in 1975. Both Obreht and Nguyen were born in some other country "but made in America" (Walsh). In his own way and metaphorically speaking, Hemon was also "made in America." He learned English as an adult and quickly became its master as if he had grown up with the language. Among other accolades, he won a MacArthur Genius grant in 2004, as well as Nguyen who won the "genius" award in 2017. Nguyen spent his first three years in the U.S. in a refugee camp in Fort Indiantown Gap, PA and then was sent to live with a white sponsor family in Harrisburg, PA where he was separated from his family. He recalls that "[a]ll Vietnamese refugees had to have sponsors to leave the refugee camp, but in our case," he points out, "no family could take all of us. My parents went to one sponsor, my ten-year brother to another, and myself to third" ("Growing Up In America"). He reunited with his family a few months later in 1978, "but that early experience as a refugee marked him 'indelibly"” (Walsh). Nguyen says, "[t]hat's when memory begins, and that's when forgetting begins for me as well, because I spent much of my life trying to forget that experience of separation and of trauma - and trying to forget what it meant to lose a country. And then as a writer and a scholar I have been trying to remember what those things mean" (Walsh). Now, he is "a man with two countries, as well as the inheritor of two revolutions" (Walsh) and, as he says, dislocation is his location ("Dislocation Is My Location" 432). His debut novel The Sympathizer (2015), which won the 2016 Pulitzer Prize for Fiction but previously "was rejected by 13 of 14 publishers 
and only accepted by an English editor who was of mixed race," blends memory, history, and a "critique of ideology, revolution, and America and Vietnam" (Walsh). Speaking of The Sympathizer at the Radcliffe Institute for Advanced Study at Harvard on February 8, 2018, "Nguyen said he wasn't interested in writing the great American novel, but a European version of the great American novel, modern and more skeptical 'of this American way of being, of this American ideal' that tends toward romance and hope" (Walsh). This could stand for Hemon's previously mentioned novels as well, who could also be seen as a man with two countries. Obreht could also be seen as a woman with two countries. In this context, all the writers in this group could be seen as men and/or women with at least two countries. In all these cases, America is one of these countries. Rabih Alameddine is a man with at least three or four countries. Alameddine, an acclaimed and provocative writer and painter, was born in Jordan, grew up in Kuwait and Lebanon, and now divides his time between San Francisco and Beirut, "but doesn't own to living in any particular place" ("This Is Also My World"). In a conversation with John Freeman at the Bookstan festival in Sarajevo, in Bosnia and Herzegovina, on October 26, 2016, Alameddine, averring that his "existence is uncomfortable for people," remarks that

the thing that's important is to never believe that there is a culture that is better than another. There are some that probably fit me more. But in Koolaids I said that in America, I fit but I do not belong, and in Lebanon, I belong but I do not fit. This tension between fitting and belonging, I think, is where I reside. I call it dislocation. I write about dislocation. And we all feel dislocation. The only difference is that we either deny it or don't deny it. ("My Existence Is Uncomfortable For People")

Many of his narratives are also "uncomfortable for people," for Americans as well as for Arabs, and, in general, for people of the world because Alameddine addresses all of us for, to paraphrase his own words, this is also his world ("This Is Also My World"). Alameddine, as well as all the other writers in this group, put America in motion in their literature and with their literature, meaning that America opens up in itself and to the world, and the rest of the world also opens to America that way - both literary and literally.

Writers in the second group include Amy Tan (born in Oakland, California, in 1952, to Chinese immigrant parents), Dave Eggers (born in Boston, Massachusetts, in 1970), Héctor Tobar (born in Los Angeles, California, in 1963, to Guatemalan immigrant parents), Jeffrey 
Eugenides (born in Detroit, Michigan, in 1960, to a father of Greek descent and a mother of English and Irish ancestry), Maxine Hong Kingston (born as Maxine Ting Ting Hong in Stockton, California, in 1940, to Chinese immigrant parents), Ruth Ozeki (born in New Haven, Connecticut, in 1956, to a Japanese mother and a Caucasian-American father), Sandra Cisneros (born in Chicago, Illinois, in 1954, to a Mexican father and a Chicana mother), Teju Cole (born in Kalamazoo, Michigan, in 1975, to Nigerian parents), Toni Morrison (born as Chloe Anthony Wofford in Lorain, Ohio, in 1931, of African descent on both sides of her family), Jennifer Egan (born in Chicago, Illinois, in 1962), Paul Beatty (born in Los Angeles, in 1962). Whether the writers belonging to this group are "natural born citizens" of the U.S. with one U.S.-born parent and other foreign-born parent, or whose both parents were either born elsewhere and are not U.S. citizens or who have become U.S citizens, or, more generally, the U.S.-born writers who descend from non-U.S.-born ancestor(s), no matter if it can be traced or not since, as previously stated, the U.S. has always been a nation of immigrants - and, more importantly, whose visionary or creative perception is, in any way, driven by a trans-American sense of identity, affiliation, and equality, also put America in motion in their literature and with their literature. For example, by depicting the past and current status of unassimilable identity of alterity, including the ways in which societies are being shaped by the normative dimensions of gender, sexuality, class, geographic place, nationality, and other similar issues, Jeffrey Eugenides's novel Middlesex (2002) transcends traditional binary thinking and paradigms in many ways. It focuses on the views, voice(s), and spatiality of the narrator and protagonist who was born as a girl and named Calliope Stephanides and, at present, has socially been identified as an adult man Cal, who is, in fact, a hermaphrodite. The book is both a Bildungsnovel about a hermaphrodite and a family saga, told from the inside and the outside. The story about Calliope's evolution into Cal is, at the same time, the odyssey of his or her or their - either the singular or nonbinary their Greek grandparents's emigration from what is now Turkey to the United States. It traces the lives of three generations of the Stephanides family. Like the genes, their storylines interact with one another to produce one body of Middlesex. As this suggests, Middlesex's genes, metaphorically speaking, are both American and Greek. The novel explores the human body as well as the body of humankind, including the anatomy of Detroit's decline (as well as the social history of the U.S.) in order to articulate the past, identify the present, and move toward the future. It also explores the aesthetics of 
normality which, as Middlesex elaborates, can never be a single story. In her novel Caramelo (2002), Sandra Cisneros, who is probably the best acclaimed contemporary U.S. Latina writer, mixes together past and present, waving between the mid- $20^{\text {th }}$ and the late $19^{\text {th }}$ century in a cinematic move from Chicago to Mexico City and to San Antonio. Moreover, Cisneros's novel, metaphorically speaking, paints a huge literary mural showing and (re)constructing a colorful blend "of PreColumbian, Mexican and North American cultures" (Salvucci 164). The novel's transmigrant narrative transcends borders and boundaries of the "imagined communities" of Mexico and the U.S. (Anderson). It especially depicts the notion of cross-cultural and transnational people's identity, focusing the border-crossing between Mexico and the U.S. Thus, the language of Caramelo is a representation of a new linguistic system developed by Chicana/o people as a result of their cultural stratification and dual linguistic inheritance. By using the technique of "code-switching" or "interlingualism," Cisneros (as well as, for example, Junot Díaz, who belongs to the previous group of writers) combines English and Spanish throughout the novel to express the ambivalence of cultural codes in addressing questions of cultural change (Madsen 22). The narrator and protagonist Celaya "Lala" Reyes, Cisneros's relative alter ego, is a mobile subject, to use Irr's words, "who receive[s] and interpret[s] cultural codes while actively transmitting and translating" her own information (29). Her navigational story shifts away from her family portrait "toward a public and political effort to think life stories that exceed those provided by the sending or receiving nations" (Irr 29). This is further emphasized by the chronology at the end of the novel, which traces Mexican history from 1519 to 2002. Also, Lala's/Cisneros's personal identity is composed of both American and Mexican elements. American as well as Mexican identity creates a variety of many different identities in the text and context of Caramelo. The author's intention is, as she explains it, "To hold up mirrors: from the Mexicans to see themselves from the point of view of the Mexican-Americans. Mexican-Americans to see themselves from the point of view of the Mexicans, Americans as seen by Mexicans, all those mirrors that get refracted" (Interview by Robert Birnbaum). As seen as a transnational, cross-cultural, and historical journey, Lala's/Cisneros's story reveals the interconnectedness of all colors of the universe. The novel depicts the universe as a rebozo caramelo, a candy-colored shawl, which fabric is made of all colors, and "it seems to require a plural and contrapuntal vision of reality" (Salvucci 197). In that way, Caramelo could be seen as a cloth of universe representing "all humanity interwoven. Pull one string and 
the whole thing comes undone" (Cisneros, Caramelo 389). As its subtitle suggests, the novel is also puro cuento, which in English means "pure invention." Therefore, even though Cisneros says her book is written for and dedicated to her father and "the immigrants," her nationally, ethnically, and culturally transcendental novel speaks to all people (Interview by Robert Birnbaum). Caramelo creates a unique vision of alternative perspectives on the present-day reality, and its new expression. It turns the concept of reality into the concept of possibility. It could be said that Teju Cole himself - who was born in the U.S. to Nigerian parents, raised in Nigeria, then moved back to the U.S. when he was 17, and now lives in Brooklyn in New York City - and his works turn both the concept of reality into the concept of possibility and the concept of possibility into the concept of reality. Cole is one of the most nationally, ethnically, and culturally transcendental contemporary writers, art historians, photographers, and performance artists. He says,

I'm a bit of a problem for the categorisers, partly because I don't fight the categories. I'm comfortable being described as Afropolitan, or African, or American, or pan-African. Or Yoruba, or Brooklynite, or black, or Nigerian. Whatever. As long as the labels are numerous. I'm "local" in many places. But I don't think this is a greater or lesser life than the one lived by people who are more grounded in one terrain. ("Afropolitan, American, African. Whatever")

Cole calls his novel Open City (2011) an "African Book" (Interview by Aaron Bady). It depicts a Nigerian immigrant of mixed African and European ancestry in the U.S. who goes on a journey from New York to Brussels and back to New York, as well as into the facets of his memory of Nigeria of his youth, and then through history, both social and personal, while encountering people from different cultures all along, He also points out that his "writing has European antecedents, Indian influences, Icelandic fantasies, Brazilian aspirations" (Interview by Aaron Bady). His book Blind Spot (2017), which especially resists categorization in many ways, creates a map of the world in an innovative way of telling that is "the form of a lyric essay that combines photography and text" (Blind Spot 324) articulating the "more" of a fraction because "[t]o look is to see only a fraction of what one is looking at" (325). The issues of race and ethnicity have always been interconnected with a (mis)conception of nationality, with race being central to the imperialist imagination, so Teju Cole and his books, among other things, contribute to the development of the transnational dimensions of black writing. Toni Morrison, the first black 
American who won the Nobel Prize in Literature, and her works especially articulate the "more" of a fraction of the black presence in U.S. literature and reality. She was awarded the Nobel Prize in 1993 as an author "who in novels characterized by visionary force and poetic import, gives life to an essential aspect of American reality" ("The Nobel Prize in Literature 1993"). Relatively as Cole, who does not abhor the labels, Morrison

has always welcomed the term "black writer". "I'm writing for black people," she says, "in the same way that Tolstoy was not writing for me, a 14-year-old colored girl from Lorain, Ohio. I don't have to apologise or consider myself limited because I don't [write about white people] - which is not absolutely true, there are lots of white people in my books. The point is not having the white critic sit on your shoulder and approve it" - she refers to the writer James Baldwin talking about "a little white man deep inside of all of us." [She explains,] "Well I never really had it. I just never did." ("I'm writing for black people ... I don't have to apologise")

Paul Beatty, the first American author who won the Man Booker Prize (Britain's prestigious literary award), which he received for his novel The Sellout (2015), a satire of U.S. racial politics, prefers to be called a "Black" rather than an African-American writer (Interview by Frédéric Sylvanise). He says that he does not like the phrase "African American" because it is "being more something or less something" (Interview by Frédéric Sylvanise). By addressing essential aspects of transnational/post-national/anational American reality, employing, however, various national and transnational perspectives of the U.S., all the writers belonging to this group rupture American nationalist myths while they are, at the same time, involved in a visionary creation of the "more" of a fraction of U.S. literature as well as of the U.S.

In spite of the fact that many Native American writers have created and developed their own visionary and creative perception of transnational/post-national/anational motion in literature, it is discussable whether Native American writers could be, at all, observed as the writers of contemporary "U.S. fiction of trans/motion," as seen as in its transcendental motion towards transnational/postnational/anational poetics of American literatures, bespeaking a continuum still evolving in its motion into the past as well as into the future. There are different streams and approaches to the questions of transnational and/or national motion of/in Native American studies in general and, correspondingly or separately, of Native American literature and its study as well. One of the many challenges currently 
facing Native American studies is the development of a repertoire of possibilities through which to read, explore, imagine, understand, and interpret the notions of transnational aesthetics. Referring to cultural studies, Robert Warrior avers that

[t]he most recent notions of the transnational have progressed in some fashion from postcolonial studies. A major reason for the lack of engagement with transnationality with Native American scholars is the widespread rejection of postcolonial studies. Though it fails to take account of the formulations of the most nuanced of postcolonial scholars, this objection is grounded in the reality that Native Americans remain colonized peoples rather than people facing postindependence realities and challenges. Thus the post in postcolonialism creates a stumbling block to engagement. (122)

Another reason why Native American (studies) scholars resist to fully engage with transnationalism, as Warrior indicates, lies in the complexity of the genesis and the development of the American studies field where, for yet another complexity of reasons, "Native American studies remains marginalised within American studies" (124). In the interdisciplinary view on Native American and Indigenous studies, Warrior further reflects on the 2006 monograph entitled American Indian Literary Nationalism he coauthored with Jace Weaver and Craig S. Womack, arguing that "the discourse on nationalism remains important to Native American literary studies because it remains the domestic and international language in which Native struggle is waged and remains a primary vehicle for fueling Indigenous imaginations" (126). Similarly, Womack points out that "there is the tendency in cultural studies to view nationalism as a pathology and a contrary tendency in Native studies to view it in terms of the survival of tribes" (37). However, Native American literary contribution to the creation and production of "U.S. literature of/in transcendental motion or trans/motion," as I view it, transcends, or, in other words, is much more than a subject of nationalism and survival, while also keeping Native American identity and affiliation, tradition and culture actively present and strong. As Jodi Byrd notices, "[w]hile indigeneity ... is an identity figured first and foremost as grounded and locatable, much of the literature written by American Indian authors demonstrates just how much indigeneity moves ... Understood as a catalyst for change against stagnation, mobility creates the possibility for the production of difference" (186). To re-paraphrase Scott Richards Lyons's words ${ }^{5}$,

\footnotetext{
5 "If anything can be considered an enduring value for Ojibwe people, it has got to be migration" (3).
} 
migration is one of the enduring values for Natives. The past, present, and future trans-internal and trans-external Native American motions are both the possibilities for visionary and creative sense of Native American movement across boundaries and borders while also retaining Native autonomy. "This sense of Indigenous movement that many scholars in the field attach to the trans-," as Byrd notes, "is indebted to Gerald Vizenor's literary and scholarly aesthetics of chance, play, and survivance" (186). She adds that,

[a]s an author who has always pursued the crosscultural in addition to the transnational in his novels including Heirs of Columbus (1991) and Hiroshima Bugi (2003), Vizenor's work embraces the inherent possibility of language to deconstruct into aleatory meaning and intent. His concept of transmotion, like Indigenous transnationalism, or the trans-Indigenous before it, depends on notions on mobility, unpredictability, and renewal. Rather than insisting on statist modes of nationalism derived through possessive territorality, Vizenor argues that "Native sovereignty is the right of motion, and transmotion is personal, reciprocal, the source of survivance, but not territorial." A few paragraphs later he clarifies, "Sovereignty is transmotion and used here in most senses of the word motion; likewise, the ideas and conditions of motion have a deferred meaning that reach, naturally, to other contexts of action, resistance, dissent, and political controversy. The sovereignty of motion means the ability and the vision to move in imagination and substantive rights of motion in native communities." Claiming sovereignty as a native right to move, act, change, and dissent, Vizenor's transmotion provides useful theoretical modes for thinking through analytic frameworks that embrace the grounded and localized relationalities of kinship networks and knowledges informing distinct Indigenous communities while also insisting on their autonomy to determine when and how they interact with, interpret, or refuse others. (186)

My theoretical perception of "U.S. literature of trans/motion" is based on and expands, or, to be more precise, it borrows, transcends, reformulates, and reshapes the concept of Gerald Vizenor's theory of "transmotion" at first to expand the study of what is known as transnational literary studies and transnational American literature so as to provide a deeper creative sense for understanding and imagining American literatures in a post-American century or, in other words, in a postcolonial America. Vizenor, for example, says that "[n]atives have been in motion by migration, trade and encounter on the continent for many centuries before contact with Europeans. The creative scenes of 
natural motion, or visionary transmotion, are at the heart of every native story. Transnational is a descriptive concept, and transmotion is visionary, a creative sense of natural motion in the world" ("Words are Crossbloods"). Accordingly, Native American writers whose visionary or creative perception of the U.S. is, in some way, driven by a transAmerican sense of natural human motion, such as Gerald Vizenor (born in Minneapolis, Minnesota, in 1934), Navarre "N." Scott Momaday (born in Lawton, Oklahoma, in 1934), Louise Erdrich (born in Little Falls, Minnesota, in 1954) and Leslie Marmon Silko (born in Albuquerque, New Mexico, in 1948), also create and shape a poetics of contemporary transnational/post-national/anational "U.S. fiction of trans/motion" in my rethinking of the issue. At the same time, their literary expressions create and shape a poetics of Native American survivance. It is Vizenor's term signifying "an active sense of presence over historical absence, the dominance of cultural simulations, and manifest manners. Native survivance is a continuance of stories" (Native Liberty: Natural Reason and Cultural Survivance 1). In the light of radical hope, it seems like both the native stories of survivance and the fiction of transnational/post-national/anational trans/motion are the radical landscapes of liberty, equality of human beings and, to use William Faulkner's words, "the old verities and truths of the heart, the old universal truths lacking which any story is ephemeral and doomed" ("Banquet Speech"). Whether they are of mixed Native American and non-Native-American origin - like Vizenor himself, for example, who is "a self-proclaimed mixblood or 'crossblood"6" (Blaeser 5) and is also a citizen of the White Earth Nation of the Anishinaabeg in Minnesota or not, Native American writers whose visionary and creative perception and narratives are related in any way and scope to the trans-internal and trans-external aesthetics, poetics, and realities could be observed as the writers of contemporary "U.S. fiction of trans/motion," as seen as in its transcendental motion towards transnational/post-national/anational poetics of American literatures, while also keeping their Native American identity, affiliation, and culture strong. A contribution of Native American writes of mixed heritage to "U.S. literature of/in transcendental motion or trans/motion," as I observe it, is of a great importance because they "are not 'marginal' as painted by some social scientists, but are actually valuable 'ambassadors,' able to live in, and interpret, both worlds" (Butler).

\footnotetext{
${ }^{6}$ A "crossblood" or a "mixedblood" in Vizenor's terminology and literature means to be of mixed Native American and European heritage.
} 
The fourth group of writers includes Chimamanda Ngozi Adichie (born in Enugu, Nigeria, in 1977, to Igbo parents, now divides her time between Nigeria, where she regularly teaches writing workshops, and the United States), Colm Tóibín (born in Enniscorthy, Ireland, in 1955), Hari Kunzru (born as Hari Mohan Nash Kunzru in London, England, in 1969, into a mixed English and Kashmiri Hindu family, now lives in New York City, New York), Kamila Shamsie (born in Karachi, Pakistan, in 1973, now a dual national of Pakistan and the United Kingdom), Mohsin Hamid (born in Lahore, Pakistan, in 1971), NoViolet Bulawayo (born as Elizabeth Tshele in Tsholotsho District, Zimbabwe, in 1981, now lives in the United States), Elif Şafak/Shafak (born in Strasbourg, France, in 1971, to Turkish parents, now lives in London, England), John Maxwell “J. M." Coetzee (born in Cape Town, South Africa, in 1940, now a dual national of South Africa and Australia; his application for permanent residence in the United States was denied in 1971 because of his involvement in anti-Vietnam-War protests). The writers belonging to this group have an experience (more or less) of living in the U.S. They show America from the outside and, at the same time, they reveal a composite way of seeing the U.S. from the inside that overcomes the insider's blind spot of the U.S. for the inside is often better seen by the outsiders. And these "outsiders" see the "more" of a fraction that creates a single story of the U.S. For example, in her famous 2009 TED talk entitled "The Danger of a Single Story," Chimamanda Ngozi Adichie, an internationally acclaimed Nigerian-born writer and a 2008 recipient of MacArthur Foundation Fellowship, among numerous accolades, says that "to create a single story [is to] show a people as one thing, as only one thing, over and over again, and that is what they become." She says that "because of America's cultural and economic power" she has many stories of America, and adds:

I've always felt that it is impossible to engage properly with a place or a person without engaging with all of the stories of that place and that person. The consequence of the single story is this: it robs people of dignity. It makes our recognition of our equal humanity difficult. It emphasizes how we are different rather than how we are similar. ("The Danger of a Single Story")

In contrast to a Western tradition of telling "single" African stories, Adichie's novel Americanah (2013) is composed of many and, also, overlapping stories, spanning Nigeria, the United States, and the United Kingdom, while capturing the emotional truth of Ifemelu, a 
Nigerian-born contemporary "(wo)man thinking"7 and a "transmigrant" (Schiller et al. 1-24). "Americanah" is a word in Nigeria referring to people who pretend to be Americanized or have been Americanized, but Americanah's foreignness in Adichie is oriented by and toward planetary consciousness. Ifemelu's American migrant experience is turbulent, but prosperous, unlike the British one of Obinze, her Nigerian boyfriend who eventually turns out to be the love of her life. She goes from her native Nigeria to the United States on a student visa, and ultimately becomes a successful blogger in the U.S. Obinze, who has always been enchanted with American culture, especially literature, cannot get a visa to post-September 11 America. When his mother, a Nigerian university professor, gets invited to an academic conference in London, she includes his name on her British visa application as her research assistant, so he gets a six-month visa to the United Kingdom. Obinze stays in London and lives on the edge of society as an illegal immigrant until he gets "removed" from the United Kingdom like "a thing without breath and mind. A thing" (Adichie, Americanah 345). Ifemelu, on the other hand, after 13 years in the United States, and now holding an American passport, decides to return to Nigeria because she chooses to live another life, seeking her individual destiny through an emotional sphere. However, the experience of both Obinze in the United Kingdom and Ifemelu in the United States is similar in something that is depicted in Obinze's thoughts at a certain dinner party in London where all the guests

understood the fleeing from war, from the kind of poverty that crushed human souls, but they would not understand the need to escape from the oppressive lethargy of choicelessness. They would not understand why people like him, who were raised well fed and watered but mired in dissatisfaction, conditioned from birth to look towards somewhere else, eternally convinced that real lives happened in that somewhere else, were now resolved to do dangerous things, illegal things, so as to leave, none of them starving, or raped, or from burned villages, but merely hungry for choice and certainty. (Adichie, Americanah 341)

Adichie's Americanah reminds us that "we are not a collection of logical bones and flesh, that we are emotional beings, that dignity and love matter as much as bread and water" (Adichie, "To Instruct and Delight: A Case for Realist Literature"). The novel thus planetary

\footnotetext{
"I here allude to Ralph Waldo Emerson's "The American Scholar" and his conception of "Man Thinking."
} 
depicts many stories of the United States, the United Kingdom, and Nigeria, containing both the spoken and the unspoken realities of our times. It turns facts into truth through the observation of intersection of four kinds of American tribalism, "class, ideology, region and race," as well as of similar kinds of British and of Nigerian tribalism, and then through the observation of gender, hair, politics, cultural reproduction and mobility, locality and spatiality, and relationality across the three continents in a manner of planetary comparatism (Adichie, Americanah 227). Americanah operates within a domain of African literature on many levels and, at the same time, it exceeds the national on an inner as well as on an outer level. Even though Adichie is not a U.S. citizen, her Americanah relatively operates within a domain that Caren Irr calls "U.S. fiction" (11). Since the space of Adichie's narrative crosses national lines, it turns fiction, or literature, on a larger scale, into the collective life of the planet. It also contributes to the worlding of American literature. The same applies to Elif Şafak, a French born Turkish writer of world fame who writes in both Turkish and English, and to some of her books dealing, in a certain way, with the U.S. spatiality such as: The Saint of Insipient Insanities (2004), The Bastard of Istanbul (2006), Black Milk (2007), The Forty Rules of Love (2009), Three Daughters of Eve (2016), as well as to Mohsin Hamid, a prominent Pakistani writer, and to some of his novels with a set of narrative coordinates referring to the U.S. such as The Reluctant Fundamentalist (2007) and Exit West (2017), and to all the other writers in this group and their narratives focusing the U.S. in some way. The narratives of the writers belonging to this group dealing with the U.S. introduce another U.S. realm that would otherwise more or less remain unseen. Thus, they also articulate the "more" of a fraction of U.S. literature as well as of the U.S., and put U.S. literature in particular and, in general, the U.S. in motion both worldly and internally.

With regard to their literary preoccupations, narrative frame, voice, and style, among other things, the writers of all four groups are involved in creation of U.S. literature in general and, in particular, of "U.S. fiction of trans/motion." Their fiction deals solely or comparatively with the American experience through a wide range of content, so they can simultaneously and transnationally coexist in other "imagined communities" of national literatures as well (Anderson). These writers either write in English or alternate between English and other language(s), or language varieties, or have influential translations of their works in English. To use Adichie's words, they do not have a single story of America ("The Danger of a Single Story"). Moreover, I would like to add one more possibility of a visionary 
perception and sense of "U.S fiction of/in trans/motion" that is a category of non-English fiction, which has not yet been translated into English, however, dealing comparatively or solely with the American narrative frame, voice, and style, and thus creating an American sense of presence in other language(s) and culture(s), as well as addressing a U.S. audience. Moving beyond a narrowly defined "American" or "U.S. literature" to a trans-American perspective, the concept of "U.S. literature of trans/motion" is grasped (as well as Irr's notion of "U.S. fiction" in a geopolitical mood) as a matter of genre. In this way, the "U.S. literature of trans/motion" revises the identity of "U.S literature" by recasting its scope and imagination in a context of nation transcending phenomena and natural or worldly human motion, both in fiction and reality. This would be one category of "U.S. fiction of/in trans/motion," as I conceive it.

\section{A Poetics of Transtextual "U.S. Fiction of Trans/motion"}

The other category of "U.S. fiction of/in trans/motion," as I would argue, deals with "transtextuality." A "trans" text and what it means could be understood differently. For example, Jessica Berman in her previously mentioned essay defines a "trans" text as one that "challenges the normative dimensions of regimes of nationality and disrupts the systems embodied identity that undergird them." As the term might operate in more than one domain, I would like to deploy it to explore some other approaches to questions of aesthetics, imagination, and perception of contemporary U.S. fiction in (trans)motion. In particular, transtextual motion of/in contemporary fiction toward a creative sense of new ways of multi-discursive, multiartistic, and/or multimedia literary expression could be seen both as a genre and principle. In any case, it is, among other things, literature's response to contemporaneity in general and, in particular, to digital technologies. Literary motion across "imagined" borders, as well as literature's migration toward some new platforms of wide possibilities of the making of "Make It $\mathrm{New}^{\text {" }}$ involves the synergies between literature and other arts and disciplines in their dialectical artistic experimentations. Since the texture of a novel is spongelike, to paraphrase Wai Chee Dimock's words (Through Other Continents: American Literature Across Deep Time 87-88), a contemporary American novel of a new form in its trans-discursive, trans-artistic,

\footnotetext{
${ }^{8}$ Ezra Pound, one of the most influential modern poets, proclaimed the maxim "Make It New" on many occasions. He also made it a title to one of his books of essays first published in London, England, in 1934.
} 
and/or transmedia storytelling, which reflects the contemporaneity that produces it, could be seen as a "transtext" or, as I would like to propose, a "transnovel." A storytelling in "transmodernism" is itself transcendence. "Transmodernism" thus could be defined as the new making of the traits of literary modernism in our contemporary moment of transition that challenges "the primacy of the 'national' as the dominant horizon of expectations and position[s] texts as moving beyond and critiquing the dichotomy of 'nation' and 'world'," as well as moves beyond and transcends borders and boundaries between and within the digital and print writing, and then overcomes a single story of the notion and concept of identity in many ways (Berman). The coexistence of the digital and print writing generates the variety of modes and principles of a "transnovel" that could be subsumed within the term "fiction of/in trans/motion," or perhaps "trans/motion fiction," both relating to the possibilities of contemporary vocabulary of the study of literature. This transitional moment of storytelling is visible in the practices of many contemporary writers all over the world. Additionally, as the "direct registrations of the internet as form and theme," in Mark McGurl's words,

there are the novels one suspects would not exist if not for the internet. They include works like Matt Beaumont's e: a novel and its sequels, in which the epistolary tradition is reborn as a long email chain; Dave Eggers's dystopia of lost privacy, The Circle; M. T. Anderson's wonderful updating of A Clockwork Orange for the digital age, Feed; and more than a few mass-market thrillers that take a newly volatile networked world as their premise. Even more significant than these direct registrations of the internet as form and theme.

Some writers of the first category of "U.S. fiction of/in trans/motion," such as Aleksandar Hemon, Jennifer Egan, and Chimamanda Ngozi Adichie, are also creators of works from what I have labeled the second category of "U.S. fiction of/in trans/motion."

Aleksandar Hemon's storytelling in The Lazarus Project is multidimensional and is always in motion. His novel's project of the new narrative engages the medium of old-fashioned photography, which gives his storytelling a new dimension as "a digital migration novel" (Irr). The photography is an inextricable part of The Lazarus Project, and the fact that it is black-and-white makes "it all look old and wise, belonging to a different, vanished, therefore better, world" (Hemon, The Lazarus Project 34). Moreover, The Lazarus Project has its unique paratextual or, in other words, metanarrative digital dimension 
on the Internet, presenting an online version of the narrative in words from the novel and contemporary black-and-white photos by Velibor Božović, a Sarajevo-born photographer, and the archival photos from the Chicago Historical Society (Hemon and Božović). Božović traveled through Eastern Europe with Hemon during his research for the novel, just like Ahmed Halibašić - Rora did with Vladimir Brik in the novel, which is one of Hemon's many ways of literary engagement with human experience that intertwines fiction and nonfiction. The online version of The Lazarus Project includes music composed in order to develop an additional sense of the world of his "transnovel" that is not defined by its relation to truth or imagination. In the light of the Biblical story of the "Resurrection of Lazarus," which is itself one of the intertexts of The Lazarus Project, Hemon's novel, metaphorically speaking, resurrects on the Internet. The Lazarus Project is a project of resurrecting a story that steps directly into a new space of storytelling to "convert information into knowledge in order to make it humanly useful" (Hemon, "There Is No Real Life").

Jennifer Egan's 2010 "transnovel" A Visit from the Goon Squad is also a technological storytelling project. More specifically, it is, so to say, a unique musical storytelling experiment. The whole novel is like an album or even like a song and, in both ways, its main component is a pause. As it is metaphorically explained in Chapter 12 entitled "Great Rock and Roll Pauses," the book is made of fragments and is fragmented in the way of great rock and roll pauses: "The pause makes you think the song will end. And then the song isn't really over, so you're relieved. But the song does actually end, because every song ends, obviously, and THAT. TIME. THE. END. IS. FOR. REAL" (Egan, $A$ Visit from the Goon Squad 271). Being a penultimate chapter of $A$ Visit from the Goon Squad, the Chapter 12 itself serves like a structural pause in the novel. Also, the Chapter 12 is written entirely as the PowerPoint slide diary of Alison Blake, a twelve-year old daughter of Sasha Grady, one of the novel's main characters, and her husband Drew Blake. As Alison's story is set in the near future, it imagines technologically more radical yet very much possible way of life of a human. The whole chapter is available on the Internet and its colorful online version musically includes the novel focused rock and roll songs and their pauses (Egan, "Great Rock and Roll Pauses by Alison Blake"). Egan's Orwellian final chapter entitled "Pure Language," which is also set in the near future, envisions a brave new world and its English language in the digital age. The English language of the novel's futuristic "Pure Language" has disintegrated into texting language: "if thr $r$ children, thr mst be a fUtr, rt?" (Egan, A Visit from the Goon Squad 
331). Similarly, yet completely different from Hemon's The Lazarus Project, Egan's A Visit from the Goon Squad is a visionary fusion of literary and musical expression, as well as of print and digital writing. While Hemon's "transnovel" includes a medium of photography, Egan's "transnovel" includes a medium of graphic expression.

As well as Aleksandar Hemon and Jennifer Egan, Chimamanda Ngozi Adichie is aware that "the real world has become the world of digital communications" (Elias, "The Commons ... and Digital Planetarity"). Adichie's "transnovel" Americanah contains her character Ifemelu's posts on her blog called Raceteenth or Various Observations About American Blacks (Those Formerly Known as Negroes) by a Non-American Black as a part of its narrative. Furthemore, in the cultural practice of "digimodernist" (Kirby) intertextuality of the new digital era, Adichie digitizes another Americanah blog on the Internet (Adichie, The Small Redemptions of Lagos). A WordPress blog entitled The Small Redemptions of Lagos, started by Ifemelu upon her return to Nigeria where the novel left off, makes the transition from the realm of fiction to the reality of the Internet. In that way, Adichie transcends borders and boundaries between blogging and fiction. Just as in Americanah, the relationship between local and translocal, as well as between the sociotechnological and the textual-cultural is symbiotic on the blog. Likewise, the relationship between the novel's internal and external blogging, as well as between blogging and fiction is symbiotic in Adichie's storytelling. Metaphorically speaking, the relationship between blogging and fiction could be seen as a kind of nervous system of Americanah.

To sum up, the narratives of Hemon's The Lazarus Project, Egan's A Visit from the Goon Squad, and Adichie's Americanah are transcendent both as print and digital storytelling projects/experiments. In both ways, individually and in a parallel of the novel's print and digital narrative, The Lazarus Project, $A$ Visit from the Goon Squad, and Americanah are mobile and interactive in their transdiscursive, trans-artistic, and/or transmedia storytelling. For this reason, each of the three novels taken as an example of new "transtextuality" could be seen as a "transnovel" without its interconnection with its digital narrative and, in that way, could also be observed as a separate form of "transnovel" storytelling or literary motion (such as Teju Cole's Blind Spot in its "transtextual" combination of photography and literary text, or Semezdin Mehmedinovićs My Heart/Me'med, crvena bandana i pahuljica in its "transtextual" combination of drawings and literary text, for example). Also, each of 
the three novels observed in its relation with its digital narrative could be seen as a "transnovel." Taken together, these innovations define a new literary form of contemporary literature that is the "transnovel" in the genre of "U.S. fiction of/in trans/motion."

\section{Conclusion, or Toward Reimagining American Literatures}

American literatures, as well as literature(s) in general are always in motion. Correspondingly, as Amy J. Elias points out, "the present is always in motion" ("Past / Future" 42). The ongoing reconfiguration of the world is a call for expanding new ways of thinking and being in the world, as well as for re-examining the past to effectively illuminate the present in its specificity. Gerald Vizenor's theoretical ideas and his discussion of "transmotion" - a natural sense of motion - has inspired me to observe a sense of postcolonial, post-national, transnational, anational, and even dislocational motion of/in U.S. fiction, with an emphasis on the late $20^{\text {th }}$ and $21^{\text {st }}$ - century American novel, created by both American and non-American authors, and then a contemporary motion of trans-discursive, trans-artistic, and/or transmedia storytelling in American literatures as well. Given the etymology of the term "transmotion," my perception, views, and critical interpretations of "U.S. fiction of trans/motion" imply that literature in general and, in particular, U.S. fiction is not a single story, as Chimamanda Ngozie Adichie would have said ("The Danger of a Single Story"). Nationalism(s) and national literature(s) are not absolute. Both natural and forced human motions in the world such as the uncountable movements, migrations, transmigrations, and then the metamorphoses of the world at the local, regional, national, and global level - all together influenced by a human motion - show that nationalism, as well as national literature is relative. The same, of course, applies to American literature. Nothing is absolute. In that way, literature itself and in itself is not absolute. Correspondingly, a transdiscursive, trans-artistic, and/or transmedia novel, or a "transnovel," as I term it, is a new expression of literature in motion. Taken together, both above mentioned categories of literature of/in motion in American literatures define a new genre of "U.S. fiction of/in trans/motion," which, on a wider scale, could be seen as a motion toward reimagining American literature. All things considered, there is always another way of seeing the world, and then literature and literary expression as well. 


\section{References}

Adichie, Chimamanda Ngozi. Americanah. Knopf, 2013.

---. "The Danger of a Single Story." TED, July 2009, www.ted.com/talks/chimamanda_adichie_the_danger_of_a_singl e_story.

---. "To Instruct and Delight: A Case for Realist Literature." Fifteenth Annual Commonwealth Lecture, March 15, 2012, commonwealthfoundation.com/resource/commonwealthlecture-2012-2/.

---. The Small Redemptions of Lagos. The Americanah Blog, americanahblog.wordpress.com/, August 27 - November 2, 2014.

Alameddine, Rabih. "My Existence Is Uncomfortable For People." Interview by John Freeman. Literary Hub, October 26, 2016, lithub.com/rabih-alameddine-my-existence-is-uncomfortable-forpeople/.

---. "This Is Also My World." Interview by Dwyer Murphy. Guernica, March 3, 2014, www.guernicamag.com/this-is-also-my-world/.

Anderson, Benedict. Imagined Communities: Reflections on the Origin and Spread of Nationalism. London and New York: Verso, 2006.

Beatty, Paul. Interview by Frédéric Sylvanise. Transatlantica, no. 2, 2013, journals.openedition.org/transatlantica/6709.

Berman, Jessica. "Is the Trans in Transnational the Trans in Transgender?" Modernism/modernity, vol 24, no. 2, April 2017, pp. 217-244, modernismmodernity.org/articles/transtransnational.

Blaeser, Kimberly M. Gerald Vizenor: Writing in the Oral Tradition. U of Oklahoma P, 1996.

Butler, Mary Ellen. "On Teaching: Gerald Vizenor." Berkeleyan, November 16 , 1994, www.berkeley.edu/news/berkeleyan/1994/1116/vizenor.html.

Byrd, Jody A. "American Indian Transnationalisms." The Cambridge Companion to Transnational American Literature, edited by Yogita Goyal, Cambridge UP, 2017, pp. 174-189.

Cisneros, Sandra. Caramelo. Vintage Books, 2002.

---. Interview by Robert Birnbaum. Identity Theory, December 4, 2002, http://www.identitytheory.com/sandra-cisneros/.

Cole, Teju. "Afropolitan, American, African. Whatever." Interview by Taiye Selasi. The Guardian, August 5, 2016, www.theguardian.com/books/2016/aug/05/teju-cole-taiye-selasiinterview-known-strange-things.

---. Blind Spot. Faber\&Faber, 2017. 
---. Interview by Aaron Bady. Post45, January 19, 2015, http://post45.research.yale.edu/2015/01/interview-teju-cole/.

Dimock, Wai Chee. "Introduction: Planet and America, Set and Subset." Shades of the Planet: American Literature as World Literature, edited by Wai Chee Dimock and Lawrence Buell, Princeton and Oxford: Princeton UP, 2007, pp. 1-16.

---. "Literature for the Planet." PMLA, vol. 116, no. 1, January 2001, pp. 173-188.

---. Through Other Continents: American Literature Across Deep Time. Princeton UP, 2006.

Eco, Umberto. "Ur-Fascism." The New York Review of Books, June 22, 1995, www.nybooks.com/articles/1995/06/22/ur-fascism/.

Egan, Jennifer. "Great Rock and Roll Pauses by Alison Blake." In A Visit from the Goon Squad. The Official Website of Jennifer Egan. http://jenniferegan.com/excerpt/a-visit-from-the-goon-squad/.

---. A Visit from the Goon Squad. Anchor Books, 2010.

Elias, Amy J., and Christian Moraru, editors. Time: A Vocabulary of the Present. New York UP, 2016.

Elias, Amy. J. "Past / Future." Time: A Vocabulary of the Present, edited by Joel Burges and Amy J. Elias. New York UP, 2016.

---. "The Commons ... and Digital Planetarity." The Planetary Turn: Relationality and Geoaesthetics in the Twenty-First Century, edited by Amy J. Elias and Christian Moraru. Kindle ed. Northwestern UP, 2015.

Emerson, Ralph Waldo. "The American Scholar - An Oration delivered before the Phi Beta Kappa Society, at Cambridge, August 31, 1837." EmersonCentral.com, emersoncentral.com/texts/natureaddresses-lectures/addresses/the-american-scholar/.

Fishkin, Shelley Fisher. "Crossroads of Cultures: The Transnational Turn in American Studies - Presidential Address to the American Studies Association, November 12, 2004." American Quarterly, vol. 57, no. 1, March 2005, pp. 17-57.

Goyal, Yogita. "Introduction: The Transnational Turn." The Cambridge Companion to Transnational American Literature, edited by Yogita Goyal, Cambridge UP, 2017, pp. 1-15.

Hemon, Aleksandar. The Lazarus Project. Penguin, 2008.

---. "There Is No Real Life." Interview by Brad Fox. Guernica, March 15, 2013, www.guernicamag.com/there-is-no-real-life/.

Hemon, Aleksandar, and Velibor Božović. The Official Site of The Lazarus Project, aleksandarhemon.com/lazarus/.

Irr, Caren. Toward the Geopolitical Novel: U.S. Fiction in the TwentyFirst Century. Columbia UP, 2014. 
Kirby, Alan. "The Possibility of Cyber-Placelessness: Digimodernism on a Planetary Platform." The Planetary Turn: Relationality and Geoaesthetics in the Twenty-First Century, edited by Amy J. Elias and Christian Moraru. Kindle ed., Northwestern UP, 2015.

Lear, Jonathan. Radical Hope: Ethics in the Face of Cultural Devastation. Cambridge, Massachusetts and London, England: Harvard UP, 2006.

Lyons, Scott Richards. X-Marks: Native Signatures of Assent. U of Minnesota P, 2010.

Madsen, Deborah L. Understanding Contemporary Chicana Literature. $\mathrm{U}$ of South Carolina P, 2000.

McGurl, Mark. "Feeling Like the Internet." Public Books, 17 January, 2018, http://www.publicbooks.org/pb-staff-favorites-2017feeling-like-internet/.

Moraru, Christian. "Introduction to Focus: American Literature Unlimited - Toward a New Geoliterary Order." American Book Review, vol. 36, no. 5, July/August 2015, pp. 3-4.

Morrison, Toni. "I'm writing for black people ... I don't have to apologise." Interview by Hermione Hoby. The Guardian, April 25, 2015, www.theguardian.com/books/2015/apr/25/toni-morrisonbooks-interview-god-help-the-child.

Nafisi, Azar. Reading Lolita in Tehran: A Memoir in Books. Random House Publishing Group, 2003.

Nail, Thomas. The Figure of the Migrant. Stanford UP, 2015.

---. "The Ontology of Motion." Qui Parle, vol. 27, no. 1, June 2018, pp. 47-76.

Nguyen, Viet Thanh. “Dislocation Is My Location." PMLA, vol. 133, no. 2, March 2018, pp. 428-436.

---. "Growing Up In America." Interview by Maureen LittleJohn. Culture, January 2016, http://culturemagazin.com/growing-up-inamerica/.

Salvucci, Mara. "'Like the Strands of a Rebozo': Sandra Cisneros, Caramelo and Chicano Identity." RSA Journal, vol. 17, no. 18, 2006-2007, pp. 163-199.

Schiller, Nina Glick, et al. "Transnationalism: A New Analytic Framework for Understanding Migration." Towards a Transnational Perspective on Migration: Race, Class, Ethnicity, and Nationalism Reconsidered, edited by Nina Glick Schiller, et al., The New York Academy of Sciences, 1992.

"The Nobel Prize in Literature 1993." Nobelprize.org Nobel Media AB 2014, www.nobelprize.org/nobel_prizes/literature/laureates/1993/. 
Vertovec, Steven. Transnationalism. Routledge, 2009.

Vizenor, Gerald. Native Liberty: Natural Reason and Cultural Survivance. U of Nebraska P, 2009.

---. "Re: Your Theory of Transmotion." Received by the author, February 11, 2016.

---. "The Unmissable: Transmotion in Native Stories and Literature." Transmotion, vol. 1, no. 1, 2015, pp. 63-75.

---. "Words are Crossbloods." Interview by Selma Raljevic. Post45, May 26, 2018, http://post45.research.yale.edu/2016/05/words-arecrossbloods-an-interview-with-gerald-vizenor/.

Walsh, Colleen. "How Viet Thanh Nguyen found his voice." The Harvard Gazette, February 15, 2018, www.radcliffe.harvard.edu/news/innews/how-viet-thanh-nguyen-found-his-voice.

Warrior, Robert. "Native American Scholarship and the Transnational Turn." Cultural Studies Review, vol. 15, no. 2, September 2009, pp. 119-130.

"William Faulkner - Banquet Speech." Nobelprize.org Nobel Media AB 2014, www.nobelprize.org/nobel_prizes/literature/laureates/1949/faulk ner-speech.html.

Womack, Craig S., "A Single Decade Book-Length Native Literary Criticism between 1986 and 1997." Reasoning Together: The Native Critics Collective, edited by Craig S. Womack, et al., U of Oklahoma P, 2008, pp. 3-104. 


\section{AMERIČKA(E) KNJIŽEVNOST(I) U POKRETU: MIGRACIJA, IMAGINACIJA, I IDENTITET U SAVREMENOJ FIKCIJI ${ }^{9}$ SJEDINJENIH AMERIČKIH DRŽAVA}

Ovim radom se nastoji predočiti i analizirati identitet američke književnosti i njegovo oblikovanje u smislu toga da je i pojam samoga identiteta fluidan, pa se time nalazi u neprestanom procesu oblikovanja, što se, prema tome, prenosi i na identitet američke književnosti. Posebna pažnja u radu se usmjerava na transnacionalnu američku književnost $i$, unutar nje, ali i općenito, na stvaranje i čitanje savremenog američkog romana. $U$ radu se diskutiraju postnacionalna i anacionalna kretanja savremene američke proze, pri čemu se $u$ fokusu nalazi američki roman dvadesetog i dvadeset i prvog stoljeća koji stvaraju i američki i neamerički autori, a u književnokritičkom i književnonaučnom čitanju i američkih i neameričkih amerikanista, između ostalih. S obzirom da se u radu književnost općenito i američka književnost posebno čitaju u svojim kretanjima preko "zamišljenih" granica, također se analiziraju i diskutiraju sinergije između književnosti i drugih vidova umjetničkih izraza savremenoga iskaza unutar savremene američke književnosti. U takvom dijalogu književnosti $i$ drugih umjetnosti, ali i književnosti i savremenosti, u radu se propituju, istražuju i analiziraju sinergije između lokalnog, regionalnog, nacionalnog i globalnog, a onda i sinergije između različitih diskursa savremenosti u savremenoj američkoj književnosti. U relativnom odmaku $\mathrm{i}$, isto tako, u relativnom nastojanju nadilaženja modela kanonskog čitanja savremene američke književnosti, ali, istovremeno, na temelju književne teorije $\mathrm{i}$ historije transnacionalne američke $\mathrm{i}$, općenito, transnacionalne književnosti, cilj rada jeste novo književnonaučno čitanje $\mathrm{i}$, time, dolaženje do novih teorijskih $\mathrm{i}$, općenito, naučnih zaključaka o transnacionalnim i transtekstualnim kretanjima (unutar) savremene američke književnosti, a onda, eventualno, i otvaranje novih pitanja nekih novih čitanja.

Ključne riječi: migracija, imaginacija, identitet, kretanje, savremena transnacionalna američka književnost/savremene transnacionalne američke književnosti.

\footnotetext{
${ }^{9}$ Riječ/termin „fikcija“ je uvezen(a) s engleskog govornog područja i može imati više značenja. U naslovnom kontekstu (i u radu, također) označava prozu, proznu fikciju, beletristiku.
} 